\title{
Analysis of functions offered by the e-government systems from the perspective of chosen group of users in Poland
}

\author{
Witold Chmielarz \\ University of Warsaw Faculty \\ of Management ul. Szturmowa 3, \\ 02-678 Warszawa, Poland \\ Email: witold@chmielarz.eu
}

\author{
Oskar Szumski \\ University of Warsaw Faculty \\ of Management ul. Szturmowa 3, \\ 02-678 Warszawa, Poland \\ Email: oskar.szumski@uw.edu.pl
}

\begin{abstract}
The aim of this article is to analyze the use of basic e-government elements by individual users in Poland in 2017. Article presents the results of research highlighting popularity, use and influence of e-government functions that support such application in reality. Seventeen core egovernment functions, most popular among respondents, were selected based on prior consultation, being the baseline for following analysis. Authors conducted the CAWI analysis to evaluate the distinguished e-government functions on a selected sample of university students. A group of over two hundred and fifty randomly selected people from the university environment was examined. This approach was guided by the structure of the article consisting of the presentation of the research hypothesis, the description of the methodology and the research sample, and the analysis of obtained results and their discussion, together with the conclusions. The results can be used by people involved in the creation and development of egovernment systems.
\end{abstract}

\section{INTRODUCTION}

$\mathrm{T}$ HERE is no definitive and complete definition of the egovernment in the literature. According to the European Commission, e-government states for the use of digital tools and information systems to deliver better quality public services to citizens and businesses [1]. Polish equivalent - epublic administration - suggests narrowing this concept to public administration [2] only, while e-government also includes services offered by the budget sector, that go beyond the scope of the commonly understood public administration [3]. This is the reason why the Central Statistical Office has defined this as the use of information and communication technology (ICT), organizational change and new competences in public administration to improve public services and planned democratic processes [4]. Public administration is understood not only as an executive apparatus of the state, but also expressed as activities targeted to organize the conditions and principles of social relations, culture, urban transportation, environmental protection, etc. [5]).

In the meantime, according to other definition, this is more electronic system of information and public services. It would therefore be more appropriate to define e-public administration as an opportunity to exploit the complexity of telecommunication tools and techniques to streamline common administrative and civil services. Gathering in one - virtual space, time and a single public administration portal all matters related to a specific category of users (citizens, business) facilitates and expands the ability to handle that [6].

In the European Union, public services are identified as guidelines for citizens that can be used via the Internet [7]. For individuals such services are: income tax, job search, social security, personal identity cards and document, vehicle registration, construction permits, police admissions, access to resources of public library, birth and marriage certificates, college registration, change of place of residence and access to health services. In Poland above presented list is slightly modified and according to project ,Wrota Polski” it looks as follow: tax registration, job search and help finding a job, getting a social pension for unemployed, handicapped and retired, obtaining a student scholarship, obtaining a personal ID, obtaining a driving license, obtaining a passport, registration of a vehicle, obtaining a building permit, reporting to the police negative events such as theft, access to public library catalogs and searching them, filing Civil status forms and acts and obtaining required copies of those, college registration, change of place of residency and sign up for a doctor's visit [8].

Citizens of the European Union more often use the electronic method of contact with governmental agencies than Polish citizens. If we consider digital interaction of citizens with public institutions (excluding e-mail), Poland with the share of $31 \%$ of persons of age 25-64 (in 2015) holds 25 th position in the ranking. Behind Poland are only three countries with lesser level of electronic interaction: Italy, Romania and Bulgaria. E-government services are divided into three groups: downloading forms, uploading of filled applications, and searching for related to service and service processing information. In this area Poland is away from leading European standards. In groups: downloading and uploading of forms and applications Poland is worse about $15 \%$ than average result for all European countries and about $26 \%$ worse in the group of gathering information about the matters realized via e-government systems. While in the top fifteen most developed European countries the percentage of filing tax returns is $32 \%$, in Poland it amounts to only $14.2 \%$; percentage of claims for social benefits in Western Europe is $11 \%$ while in Poland $0.7 \%$; use of public 
libraries in Poland is $3.1 \%$ compared to the average of $10 \%$ in Western Europe, etc. [9]. The above results indicate that Polish citizens despite filling tax declarations, don't use more advanced services of the e-government e.g. fulfillment of e-forms. The most common reasons for this state of use of e-government interaction is lack of sufficient competence to do that online $(11 \%)$, concerns about personal data security $(11 \%)$ problems with digital signature or digital ID $(3 \%)$ and lack of specific functionality $(2 \%)$ [10].

Considering above, the main purpose of this study was to determine whether this adverse status noticed 3-4 years ago was maintained. In addition, it was attempted to find out whether the current state of e-government in Poland satisfies people who are willing to use it and to what extent. Identifying the current status of functionality provided by the e-government systems may become the basis for the proposed changes in this area.

\section{ReseARCh METHOdOLOGY}

Provided in the introduction statistical analysis are not optimistic. Those indicate rather low interest of potential users of electronic administration systems in the current form. The article neither perform characteristics of those services, nor critical analysis of accompanied functionality. The authors faced the difficult task of selecting, a priory, the range of egovernment services that are the most popular for the analyzed population and on the one hand, are consistent with the findings and definitions of the e-government used in definition of the European Union recommendations.

Research method consists of following steps: creation of list with all services that are possible to be provided via egovernment systems; conducting the "popularity test" of used public services on a limited group of twenty-five people of the surveyed population; creation of survey questionnaire based on returned from "popularity test" answers, adjusted in its essential part and the language and scope of the question to the respondents' understanding of the basic functions of e-government; sending notifications to potential respondents and analysis and discussion of the results; the conclusions of the survey and the consequences therefrom.

Research was executed based on Computer-Assisted Web Interviewing (CAWI) method [11] on selected sample of university students at the end of February 2017. CAWI is an Internet surveying technique in which the interviewer follows a script provided in a website [11]. 254 respondents from academic environment took part in the survey. 197 participants provided full response to the survey, that is $76 \%$ of the whole survey population. Despite pre-consultation, questions still were reported as difficult for respondents. Survey contained following parts: introductory questions on the frequency and technology of access to the Internet and frequency of access to e-government; the main part consisting of: questions about another e-government service, resulting from the European Commission's assumptions, together with the question of the quality of the service in relation to the same service performed in the traditional way and the results and the degree of satisfaction resulting from it; open questions addressing the future of e-government and demographic and social data questions.

The survey was distributed online via servers of Faculty of Management Of University of Warsaw. Participants were limited only to academic environment and were recruited from students of all types studies at Faculty of Management, University of Warsaw, Academy of Finance and Business Vistula. The survey completed over 250 respondents, who evaluated the whole issue. 76 percent of participants submitted correctly completed full questionnaire. Among the respondents there were $78,17 \%$ of women and $21,83 \%$ of men. An average age of the respondent was 21,39 years (out of range 19-23 years).

Among respondents 4,06\% already finished the Bachelors studies and $0,75 \%$ finished Masters level. Approximately $69 \%$ of the respondents were students and $30 \%$ were working students. Almost $28 \%$ of respondents declared the origin of the city with the number of over 500 thousand of inhabitants, $12,18 \%$ lived in of the cities of 100-500 thousand inhabitants, over $13 \%$ lived in the cities with 50-100 thousand inhabitants and almost $24 \%$ of the respondents declared to live in the cities up to 50 thousand inhabitants and $22,34 \%$ declared origin of the rural area.

Selection of the sample group was decided after analysis of D. Batorski research [12], who proved that the highest level of Internet activity is within the age group of 16-24 and 25-34 (almost 70\%), following the newmarketing.pl [13] service data, where $34 \%$ of all beneficiaries of all online services (including mobility) - were coming from the age group of 18-34 (similar values are given by other sources, e.g. MarketingAutomagic.pl [14]). The accepted assumption about the age of customers is at the same time an advantage of the choice that reduced the potential for generalization and also increase the positive results of the analysis.

\section{AnAlysis AND DISCUSSION OF RESULTS}

The most essential findings of the research are presented below.

A significant number of interviewees (97.97\%) responded to the question about the frequency of use the Internet, that they use it several times a day, and additionally not less than once a day answered $1.51 \%$. Only $0.51 \%$ of respondents use it rarely - a few times a month. In the meantime, the answer to the question whether respondents often use functions of the e-government is clearly disappointing. Most of people $(39.59 \%)$ use such functions very rarely or not at all (18.78\%), and additionally $15.23 \%$ respondents handle public matters traditionally, which is a testimony to the fact that almost $75 \%$ of respondents does not participate in the benefits of the functionality of this area.

The first question concerned the most popular function of e-government - on-line tax settlement. Almost $45 \%$ of respondents have confirmed that they have used often (or have used from the beginning of such availability) or several times. $8.63 \%$ of respondents never used such features. The traditional way of doing taxes is declared by nearly $30 \%$ of respondents. Almost $60 \%$ of those who declare to use this 
system, admit that on-line tax settlement is better method than visiting a Tax Office, while the opposite opinion shows $8,12 \%$ of respondents.

At a similar level, was rated the opportunity to use the Internet for job placement. In this case $41 \%$ of respondents used this advantage several times, and $16.24 \%$ used at least once. Unfortunately, more than half participants did not use it at all, and $8.12 \%$ used traditional methods of job-seeking. This resulted that only slightly more than $19 \%$ of respondents who use such form of contact rated online employment searching as better than traditional methods, and almost the same number claimed to be equal. By contrast, over $56 \%$ have no opinion on this subject. From the other hand, only $3 \%$ believe that online job searching produce worse results than traditional.

Generally, similar distribution of responses was obtained in response to the question related to participation in the online social security service for individuals. More than a quarter of respondents declared that they used this form of contact at least once. But almost the same - 2\% - claims to handle such cases in a traditional way, and as many as $52.28 \%$ do not use at all such services available on the Internet.

Much better proportions are noticed in the process of using online services related to driving area. More than $58 \%$ of respondents used this service at least once, $28 \%$ did not use it. Almost $20 \%$ used traditional methods. More than $56 \%$ of respondents consider it to be equal to the traditional, and only $2.5 \%$ assess it worse. $38 \%$ have no opinion on this subject.

Only slightly over $25 \%$ of respondents participated in the online process of passport service, more than $38 \%$ of respondents handle passports traditionally, 3\% of respondents do not use this online service. Only $14 \%$ believe that online methods are better than traditional, more than $10 \%$ recognize those services as equivalent, but $66.50 \%$ do not have any opinion.

Even worse were the results of online personal identification services. At least once, $37 \%$ of respondents used this possibility out of those two thirds only once. On the other hand, $4 \%$ of the respondents used traditional methods. Those who used on-line services, claimed that this was a better way than traditional methods $(26 \%)$, but more than half $(54 \%)$ did not have an opinion on this.

Almost $48 \%$ of respondents don't use the registration and de-registration of vehicles process, $34 \%$ of participants handle it traditionally. Only $18.28 \%$ of respondents supported these activities using ICT techniques. Only $18 \%$ believe that the results were better or equal to traditional ones. Nearly $75 \%$ have no opinion on this subject.

$76 \%$ of respondents do not use online services to obtain construction and demolition permits and $20 \%$ handle it traditionally. Only $4 \%$ participants use the facilities in this regard. $87 \%$ respondents have no opinion about the primacy of online methods, and almost $80 \%$ think that the results of the systems used in this field are almost none.

Approximately $19 \%$ of respondents used the Internet to obtain the required documents from the Office of Civil Status. Only one quarter deals with this matter traditionally, and
$55 \%$ have never had a need to use those services at all. However, less than $10 \%$ think that online methods are better than traditional, and 7\% recognize the equivalence between traditional and web supported. But still $74 \%$ have no opinion on this subject. Two thirds believe that currently the results of use of such systems are almost nonexistent.

The opposite is the situation with the use of on-line health service. At least $66.7 \%$ of respondents used it at least once, and almost all of them considered it at least enough, and only $23.9 \%$ handle it traditionally. Therefore, $66 \%$ consider such services to be better than traditional, and only $29 \%$ of respondents have opposite opinion. Even when treating medical services in the general way as were used in the survey (contact with health services over the Internet), it is not possible to notice that they are at low level.

There is also an advantage of using online public opinion polls and public mailing lists - 53\% over the people who don't use such services $-47 \%$. On the other hand, on line reading is positioned very well, almost $81 \%$ of the respondents experienced this form of communication with culture via the Internet, while $78 \%$ consider it to be at least equivalent to traditional methods and $100 \%$ are glad with it.

Additionally, due to the selected research sample, students were asked about the possibility to apply online for admission to the university, and over $94 \%$ of the respondents used this form of communication and considered it better or at least equivalent to the traditional forms as well as they confirmed that participants were satisfied with this form.

\section{CONCLUSION}

To sum up the above considerations it should be noted that average results of use of the e-government systems in 2016 do not differ much from the results described in the survey carried out in Poland and Europe in 2013-2015. The fact is indicated by nearly $35 \%$ of users of e-government systems in 2016, compared to $31-33 \%$ in other studies [9], [15] and similarly $30 \%$ for the tax settlement (compared to $31 \%$ in the European Commission databases [7]). The resulting differences may be caused by the methodological discrepancy or characteristics of the selected test group.

In summary, conducted surveys, supplemented by comments from respondents, give the following conclusions:

- the level of electronic services in e-government area in Poland is considerably lower than in most of European countries. In the official sphere this situation has not changed since the last three years,

- $\quad$ some revival can be noted in the social sphere (culture, public opinion, public health services, etc.), but the opinion expressed by respondents shows that respondents do not always distinguish public administration services from private services,

- the basic problem in using of e-government services is lack of ability to handle the whole matter from start to finish via the Internet. The small range of available services are often limited to the ability to print out a document, which is even more disconcerting than attracting potential users, 
- another element that deduces the benefits of the egovernment is a need to appear personally in the office despite the settlement of some cases over the Internet,

- there is serious level of a mistrust to the local and central administration as well as perception of a potential lack of internet security,

- for the respondents the decision to use the e-government function is also balanced with the security of their personal data while handling the matter,

- there are gaps in information how to handle a given matter or the information is not clear for the user and he lack of proper marketing and information about possibility to handle public administration issues over the Internet and education about related benefits,

- there are technical problems and e-government services are incorrectly designed from the user's point of view and are described in an incomprehensible language,

- $\quad$ sometimes there is no response from the officials or lack of answer to the question and the low competence of officials informing how to fill out the web forms

- in this situation it is not surprising the large share of traditional methods in dealing with official matters.

The above conclusions show a number of potential postulates for e-government, the most important considered by authors are:

- $\quad$ the ability to provide universal functionality to fill applications and documents without the need for an electronic signature as is in its current form, accompanied with feedback on whether the document has been properly filled out, or reverse information how to correct errors,

- the dissemination of information regarding e-government, as many people simply do not know about the possibility of settling official affairs and education on how to use online services and forms to convince unconverted to use this method to contact with the public offices or institution,

- proper design of e-government services, making them in a user-friendly language, not necessarily professional, maximizing the simplification of forms and minimizing of information taken from the citizen, especially when already present in the databases of the office or institution,

- and above all, the unification, simplification and integration of numerous legal and organizational regulations and restrictions that hinder contact with public administrations and the use of e-government.

The presented study has preliminary character and was concerned on the distinguished population. Its nature was based on the results obtained from test group and should therefore be extended to include a broader social cross-sectional survey and focus more on the use of e-government by citizens rather than on the current state of its activity and acceptance.

\section{REFERENCES}

[1] https:/ec.europa.eu/digital-single-market/en/public-servicesegovernment\#Article, accessed March 2017

[2] http://orka.sejm.gov.pl/WydBAS.nsf/0/9BBD52682ADC88EEC1257 A30003C8B7F/\$file/3_19.pdf, accessed March 2017

[3] Marciniak M. (2013), Rozwój i wykorzystanie rozwiązań e-government w polskiej administracji publicznej, [w] Kultura i administracja w przestrzeni społecznej Internetu, red. J. Kinal, Z. Rykiel, Wydawnictwo Uniwersytetu Rzeszowskiego, Rzeszów , p. 120; DOI:10.7862/rz.2014.hss.12

[4] Bogucki D. (2005), e-Government w Unii Europejskiej, „Elektroniczna Administracja", nr 1

[5] Izdebski H., Kulesza M. (2004), Administracja publiczna, zagadnienia ogólne, Liber, Warszawa

[6] https://mfiles.pl/pl/index.php/E-Government, accessed March 2017

[7] https://joinup.ec.europa.eu/sites/default/files/ckeditor_files/files/eGov ernment_Poland_June_2016_v4_01.pdf, accessed January 2017

[8] W. Kuta, "Platforma ePUAP jako znaczacy element e-government w Polsce" in Zeszyty Naukowe WSHE, t. XXXIX, Nauki Administracyjno-Prawne, H. Stępień E. Wyższa Szkoła Humanistyczno-Ekonomiczna we Włocławku, 2014, pp. 16

[9] Śledziewska K, Zięba D,: E-Administracja w Polsce na tle krajów Unii Europejskiej, Digital Economy Lab UW, Warszawa, 2016

[10] Raport: e-Government in Poland, EU, June 2016, Edition 18.1, eGovernment_in_Poland_June_2016_v4_01.pdf, accessed March 2017

[11] Survey Expression, CAWI, http:/www.surveyexpression.com/ surveys/survey-articles/computer-assisted-web-interviewing-cawi, accessed March 2017

[12] Batorski D. (2015), Korzystanie z mediów 2015, Warunki i jakość życia Polaków, - Raport Diagnoza Społeczna.

[13] http://nowymarketing.pl/a/5207, handel-mobilny-w-polsce-rosnie-3razy-szybciej-niz-e-ommerce-ogolem, accessed February 2017

[14] https://marketingautomagic.pl/2015/03/polski-handel-mobilnyrozwija-sie-szybciej-niz-e-commerce/, accessed March 2017

[15] http://di.com.pl/co-trzeci-polski-internauta-korzystal-z-eadministracji-badania-maic-49366, accessed January 2016

[16] https://pl.scribd.com/doc/201131630/Raport-e-administracja-woczach-internautow-2013, accessed February 2017. 